\title{
Spontaneous tumour regression
}

\author{
Dinah Seligsohn
}

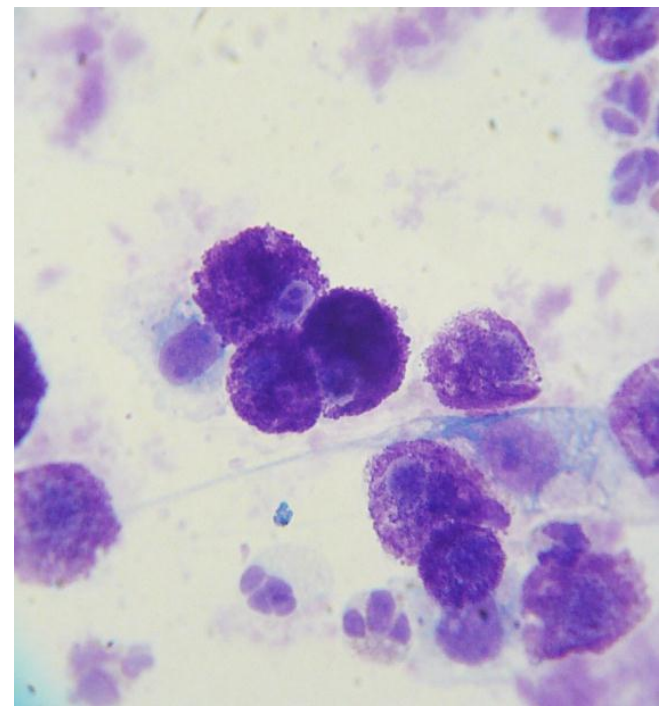

Självständigt arbete i veterinärmedicin, $15 \mathrm{hp}$

Veterinärprogrammet, examensarbete för kandidatexamen Nr. 2011: 34

Institutionen för biomedicin och veterinär folkhälsovetenskap

Uppsala 2011 

Sveriges lantbruksuniversitet

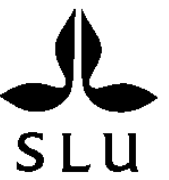

Fakulteten för veterinärmedicin och husdjursvetenskap

\title{
Spontaneous tumour regression
}

\author{
Spontan tumörregression
}

Dinah Seligsohn

\section{Handledare:}

Eva Hellmén, SLU, Institutionen för anatomi, fysiologi och biokemi

\section{Examinator:}

Mona Fredriksson, SLU, Institutionen för biomedicin och veterinär folkhälsovetenskap

Omfattning: $15 \mathrm{hp}$

Kurstitel: Självständigt arbete i veterinärmedicin

Kurskod: EX0700

Program: Veterinärprogrammet

Nivå: Grund, G2E

Utgivningsort: SLU Uppsala

Utgivningsår: 2011

Omslagsbild: Joel Mills

Serienamn, delnr: $\quad$ Veterinärprogrammet, examensarbete för kandidatexamen Nr. 2011: 34 Institutionen för biomedicin och veterinär folkhälsovetenskap, SLU

On-line publicering: http://epsilon.slu.se

Nyckelord: Spontan tumörregression, tillbakabildning, tumör, immunförsvar, histiocytom, melanom, hemangiom, papillom, mastocytom

Key words: spontaneous tumour regression, involution, remission, tumour, immunesystem, histiocytoma, melanoma, hemangioma, papilloma, mastocytoma 



\section{INDEX}

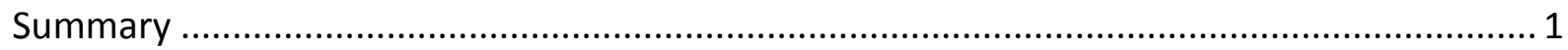

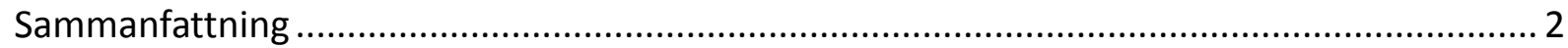

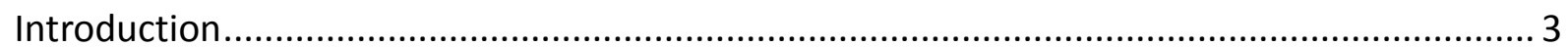

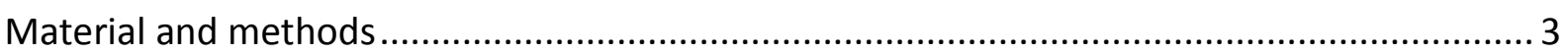

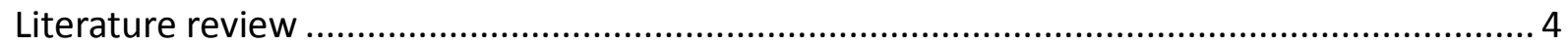

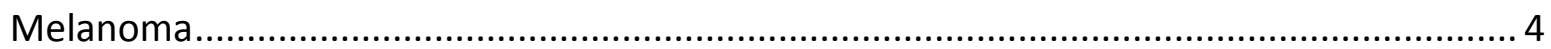

Melanoblastoma-bearing Libechov minipigs .......................................................... 4

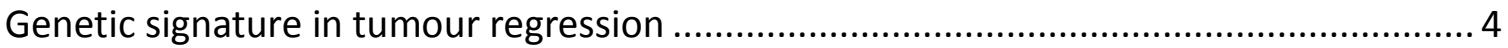

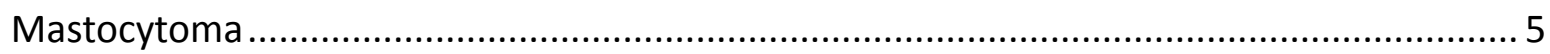

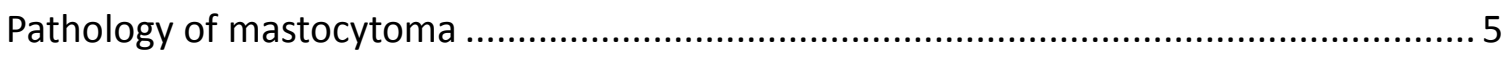

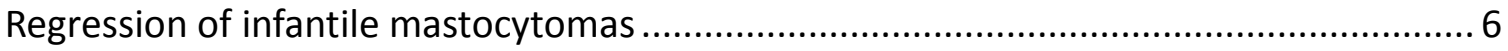

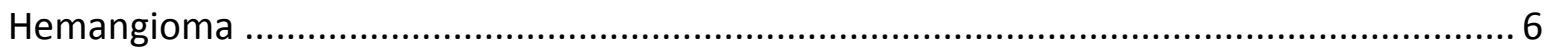

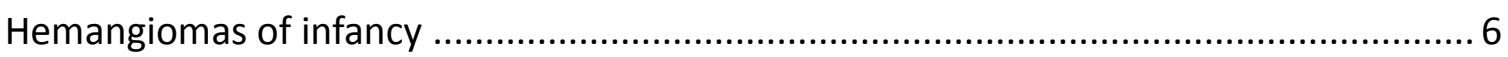

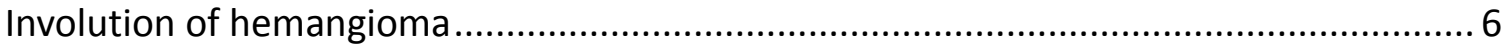

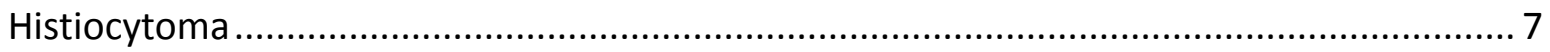

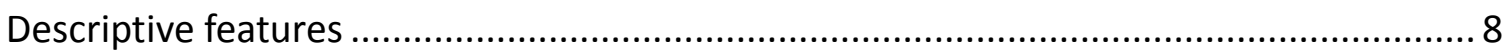

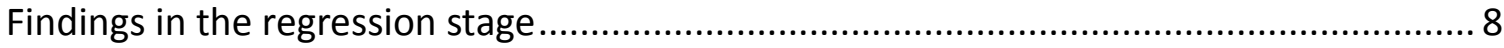

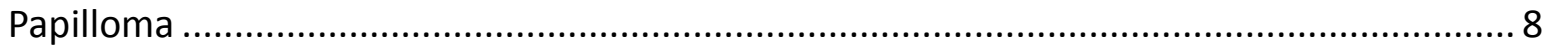

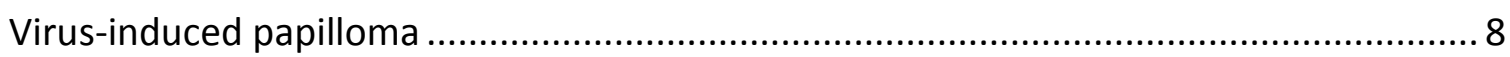

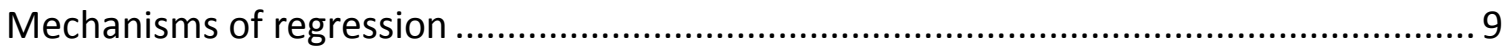

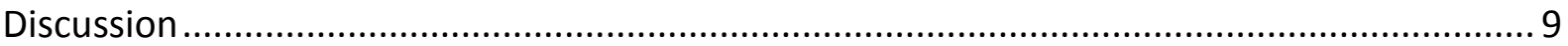

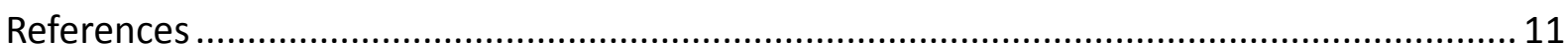





\section{SUMMARY}

Complete tumour regression is the optimal outcome of cancer therapies. There are however types of tumours that naturally regress. Most of these are benign, dermatological and have an early onset in life. This literature study aims to elucidate the mechanisms behind spontaneous tumour regression. In Libechov Melanoblastoma-Bearing minipigs, an animal-model specifically bred to develop malignant melanoma, the tumours usually involute within three months. This has been proven to be the effect of a lymphocytic infiltrate, predominated by cytotoxic T-cells. An epidermotropic myeloid tumour of Langerhans cell origin, frequently seen in young dogs, is called histiocytoma and is known to have a very brief proliferation followed by a quick remission. The involuting process is due to extensive lymphoid infiltrate. In hemangioma, rapid growth of the tumour is followed by a regressing stage that has been linked to apoptosis, possibly induced by mast cells. As in the case of hemangioma, infantile mastocytomas are known to regress before the child reaches puberty. The series of events behind the remission remains poorly investigated, but is thought to be connected to increased apoptosis of tumour cells. Another self-involuting tumour of the skin is the virus-induced papilloma, which self-keratinizes to oblivion. The infected cells become terminally differentiated and thus lose their ability of mitosis. There appears to be no overall explanation as to why and how spontaneous tumour regression occurs, but different types of tumours seem be unique from one another. 


\section{SAMMANFATTNING}

Målet med cancerbehandling är en total tillbakagång av den maligna tumören. Det finns dock dokumenterade cancerfall där hela tumören gått i regress utan att behandling satts in. På den benigna sidan finns tumörtyper där spontan tumörregression är ett välkänt faktum. Gemensamt för de flesta av dessa är att de är lokaliserade till huden samt att de ofta bildas tidigt i livet. Denna litteraturstudie syftar till att utreda bakomliggande mekanismer till spontan tumörregression. Melanoblastom-bärande Libechov-minigrisar är en försöksdjursmodell speciellt framtagen för att studera patogenes och regression av malignt melanom. Djuren utvecklar maligna tumörer inom tre månader post partus, vilka sedan går i regress inom kort. Man har i studier visat att detta beror på att tumörcellerna stöts bort av grisarnas immunförsvar. En liknande mekanism har påvisats i kutant histiocytom, vilket ofta drabbar unga hundar. I båda fallen drivs tumörregressionen av ett T-cellsdominerat immunsvar huvudsakligen bestående av cytotoxiska T-celler. Infantilt hemangiom är en annan tumör som går tillbaka spontant. I studier har detta visats bero på en ökad apoptos av tumörcellerna och en del resultat indikerar att mastceller är den inducerande faktorn. Precis som i hemangiom tros apoptos vara en förklaring till att infantila mastocytom går i regress. Terminal differentiering är den bakomliggande orsaken till varför virus-inducerade papillom så småningom tillbakabildas. När cellerna blir slutgiltigt differentierade förlorar de sin förmåga att dela sig och blir tillslut keratiniserade och dör. Det verkar inte gå att hitta en generell förklaring till varför en del tumörer går i spontan regression. De fall som finns skildrade i litteraturen uppvisar vitt skilda mekanismer. 


\section{INTRODUCTION}

The development of tumours in mammals is seen frequently and is closely related to ageing. The more times a cell undergoes mitosis, the higher the risk of mutation occurring in the DNA. However, tumour development is not completely isolated to maturing populations, but can appear at any age. Furthermore, neoplasms could be divided into two categories: malignant and benign. The malignant tumour, usually referred to as cancer, is one of the leading causes of death in the world (Elston, 2004).

However, sometimes tumours undergo natural remission without being treated. Mostly these tumours are benign, but there are known cases in which cancers (malignant tumours) have regressed and the patients have fully recovered (Elston, 2004).

This literature study aims to answer the question of which mechanisms are responsible for spontaneous tumour regression; is there a general series of events or are all cases unique from one another? The tumour types examined in this study all exemplify natural involution and thus, were chosen to give a deeper insight into the subject.

Understanding the mechanisms behind self-generated involution of tumours could help to predict tumour behaviour, to comprehend the development of tumours and most important of all, could be used in the development of more effective cancer therapies.

\section{MATERIAL AND METHODS}

Since tumour research is a very progressive field in the world of science, the number of articles published is too numerous to count. Therefore it is usually wisest to carefully limit search criteria to facilitate the process of finding relevant information. In time, it became clear that the field regarding spontaneous regression of tumours remains relatively unexplored and there is not much written on the specific subject. In particular on the veterinary side, adequate data was missing; subsequently this essay contains facts taken from both human and animal studies.

The references used were found through databases such as PubMed, Google Scholar and Web of Science. The main keywords used in different combinations were "spontaneous, selfgenerated, tumor/tumour, tumors/tumours, regression, involution, remission, mechanism, mechanisms, mastocytoma, mast cell tumor, cutaneous, hemangioma, histiocytoma, HPV, melanoma".

Delving into research obtained from some articles directly led on to other work that had been done in similar fields. To be able to present a sufficient background to some of the parts in the essay, review-articles were used. 


\section{LITERATURE REVIEW}

\section{Melanoma}

\section{Melanoblastoma-bearing Libechov minipigs}

To closer study the pathology, tumour progression and tumour regression of melanoma, several animal-models have been developed for this specific purpose. A frequently used animal-model is the melanoblastoma-bearing Libechov minipig (MeLiM swine model). The breed is exposed to a very high incidence $(50 \%)$ of malignant melanoma and piglets usually develop tumours within three months after birth. The tumours share fundamental characteristics with human malignant melanomas and can be classified according to the same system to a large extent. Clinically, the melanomas appear flat to exophytic and of varying size and varying intensity of pigmentation. Occasionally, ulceration of the lesion is seen. It is not uncommon that different types of melanomas can be found in the same animal. Histologically, melanin-filled keratinocytes are abundant along atypical melanocytes. There are very few lymphatic cells infiltrating the tumour. The neoplasms commonly display a highly invasive growth and on post-mortem examination, extensive metastasising is usually shown, especially in rapid growing tumours (Vincent-Naulleau et al., 2004).

\section{Genetic signature in tumour regression}

Approximately three months after developing melanoma, regression of the tumour is seen in the MeLiM minipig. Since the tumour onset occurs at a very early stage in the life of the animals, both proliferation and regression of the tumour occurs in a continuum, making it difficult to distinguish distinct phases of the process. However, remission of the primary tumour is generally characterised by a drying of the tumour, followed by keratosis and a reduction in size. The pigmentation of the melanoma fades and the lesion becomes grey. A flattening and softening of the surface is common, finally leaving a scar or no visible trace of the tumour. On a microscopic level, dense infiltrates of lymphocytes are seen in the tissue with a foci consisting of fibrous tissue. There is also a high abundance of heavily pigmented histiocytes. Regression of the tumour is usually accompanied with depigmentation of hair, iris and skin. The loss of pigment is sometimes localized to a halo around the regressing lesion, but can include the whole body (Vincent-Naulleau et al., 2004).

In 2008, Rambow et al. (2008) performed a study on tissue samples and cell cultures collected from MeLiM melanomas to explore if a significant alteration in the gene expression throughout the course of proliferation and regression in the tumour could be discovered. The results were obtained using suppression subtractive hybridization (SSH). Based on this study's results, 1411 genes were found to have an altered expression during the period looked at and these were further classified into different groups depending on their functions. The gene groups were as follows: cell death, cell cycle, cellular movement, immune response, hair and skin development and function, DNA-replication, DNA-recombination and DNA-repair. At an early stage in the regression, a number of genes belonging to the groups cell cycle, DNAreplication, DNA-repair and DNA-recombination were significantly down-regulated. Most of these genes were connected to the cell cycle and DNA-repair-groups, coding for cyclins, 
cyclin dependant kinases and spindle and chromosome related proteins. $70 \%$ of the genes were directly related to mitosis. This suggests that the cell cycle and proliferation of the tumour cells are arrested shortly into the process of involution. Furthermore, up-regulation of macrophage/monocyte related genes were detected, explaining the elevated numbers of histiocytes seen in the tumour. This was interpreted as the first attempt of the immune system to eliminate highly immunogenic cancer cells. Later in the remissive state, a number of immune-system related genes were noticeably up-regulated, coding for T-cell receptors (TCRs), T-cell cytokines, effector molecules such as perforin and granzyme B, and immunoglobulins such as IGHM (IgM chain C region). Flow cytometry was used to determine the origin of the tumour infiltrating lymphocytes (TILs) which appeared to consist mainly of $\mathrm{CD}^{+} \mathrm{T}$-cells (CTLs). At a very late stage in the regression of the tumour, the MLANA-gene, coding for a melanosomal protein, was markedly down-regulated, along with the down-regulation of genes involved in the melanogenesis (ex. SILU, SLC24A5, OCA2, CITED1, TYR). This could explain the major decrease in melanoma cells. Finally a large number of apoptopic genes (for instance CLU, ELMO1, PLEKHF1, THY1) was higher expressed in the late stages of the regression along with a higher expression of ubiquitin D (which serves as a marker for proteins ready for destruction) and clusterin (an apoptosisrelated protein). To sum up the results, the malignant melanoma seen in MeLiM-minipigs undergoes spontaneous involution. At an early stage of regression, the cell cycle is halted and histiocytes are recruited to the tumour site. Later on, the tumour is infiltrated by $\mathrm{T}$ lymphocytes, mainly CTLs and expression of genes with immune-response promoting functions are up-regulated which consequently leads to increased apoptosis and complete involution of the melanoma. What initially triggers this involution remains undiscovered (Rambow et al., 2008).

\section{Mastocytoma}

\section{Pathology of mastocytoma}

Aggregates of mast cells are called mastocytomas and are usually the clinical manifestation of pathologically increased blood levels of mast cells, a condition named mastocytosis (Valent et al., 2001). The pathogenesis still remains relatively unknown although recent studies hint that mutations in the protooncogene, c-KIT (sometimes called stem cell factor, SCF), that codes for the receptor for mast cell growth factor may play a part in the development of mastocytosis (Longley et al., 1996). Mastocytomas usually appear as skin lesions, moreover, other internal organs might be involved, especially in adults (Valent et al., 2001). Cutaneous mastocytomas can be further classified into different subgroups. The urticaria pigmentosa is the most common form and shows as red-brown regular-shaped macules or papules. In infants, cutaneous lesions normally present as solitary or multiple mastocytomas. These are known to undergo involution within a few years. Less frequently seen are the diffuse cutaneous mastocytosis, the erythrodermic diffuse cutaneous mastocytosis and telangiectasia macularis eruptive persistans (Hartmann \& Henz 2001). 


\section{Regression of infantile mastocytomas}

In infants, the remission of cutaneous lesions is a common occurrence. In most cases the tumour first appears within a couple of months after birth. A proliferative phase (PS) is followed by a regression stage (RS) and the lesion will normally vanish before the child reaches puberty (Hartmann et al., 2003).

A comparative study between the two phases showed that during PS the mast cells expressed proliferative cell nuclear antigen (PCNA). Dense infiltrates of mast cells in the dermis were seen histologically together with drawn out epidermal ridges. In RS no PCNA-expressing cells were found, indicating that the proliferation had ceased completely. The area of the mast cells seen in the RS was significantly larger than the one found in PS and the amount of cells positive of SCF had increased. SCF can serve as a growth factor for mast cells which could be used as an explanation as to why the remaining mast cells appeared larger than in the PS. The pathohistological findings in the RS revealed a clear disparity in the number of mast cells present in the dermis. Small groups of mast cells still dwelt in mid-dermis, but instead of massive aggregates in the higher dermis, slight fibrosis was found and the epidermal ridges were levelled out. Increased numbers of apoptotic mast cells were revealed. This suggests that regression of mastocytoma involves loss of proliferation and an enhanced number of apoptotic mast cells. Autocrine effects of SCF probably serve to promote the remaining mast cells in the RS (Inoue et al., 2002).

The mechanisms behind spontaneous regression of infantile mastocytomas are yet to be fully understood.

\section{Hemangioma}

\section{Hemangiomas of infancy}

The most frequently seen neoplasm in infants is cutaneous hemangioma. It is known to grow rapidly in neonates and then slowly involute. Hemangiomas are seen in 1,1-2,6 \% of infants, at the age of one year the rate is $12 \%$. Premature children weighing under a $1000 \mathrm{~g}$ have a $22.9 \%$ chance of getting hemangioma which suggests that placental factors might be involved in the pathogenesis. The tumour itself is in most cases benign and relatively harmless although complications often arise due to the localization (Bruckner \& Frieden 2003).

The macroscopic manifestation is dependent upon which level in the dermis the hemangioma is to be found. Growing superficially, it normally appears as a lump of varying size, soft to palpate, alopecic and highly erythematous. A deeper lying tumour is naturally less noticeable and may just show as a raised bluish macule. Combined types also exist, with both the deep and superficial features (Bruckner \& Frieden 2003).

\section{Involution of hemangioma}

Hemangiomas are common tumours in infants. As mentioned earlier, the hemangioma starts growing rapidly within a few months of birth. The peak of proliferation occurs after 9-12 
months, followed by a slow involution. Generally it regresses about $10 \%$ per year (Bruckner $\&$ Frieden 2003). Congenital hemangiomas are less known to undergo a proliferative phase and consequently seem to involute quicker (Boon et al., 1996).

On microscopical examination in the proliferative phase, fat, well-differentiated, highly mitotic epithelial cells are organised in layers, sometimes forming lumens (Bruckner \& Frieden 2003). During the proliferating, involuting and the completely involuted phase, the endothelial cells express a large variety of different growth factors. Boon et al (1996) showed in a study that TIMP 1, an inhibitor of neovascularisation, was expressed in the involuting phase together with SMC-actin, a marker of mature smooth muscle cells with inhibiting effects on endothelial proliferation. Furthermore, the tissue did not stain for vascular endothelial growth factor (VEGF) in the involuting stage. The authors suggested that angiogenic peptides affect proliferative cells to differentiate. The differentiated cells supposedly express mediators that results in the activation of mast cells and expression of TIMP 1. The activated mast cells are thought to produce growth factors and interferons, which together with TIMP 1 leads to an involution of the tumour (Boon et al., 1996).

More recent findings propose that the involution of hemangioma is strongly connected to apoptosis, although the factor triggering the switch to regression still remains unexplored (Razon et al., 1998). There are also reports of an up-regulated expression of the gene coding for mitochondrial cytochrome $b$ (Hasan et al., 2001)(. Modulation of the electron transport chain could serve as an explanation as to why the cells undergo apoptosis (Bruckner \& Frieden 2003).

The theory that presents the mast cell as the active inducer of involution is supported by a study where an increase in the activation of interferon-genes during the regression stage was shown (Ritter et al., 2002). In another study, it was found that cytoplasmatic mast cell granules stained for two important markers of apoptosis, Clusterin/ApoJ. Endothelial cells in the lesion also expressed Clusterin/ApoJ, which indicating that the mast cell forced the endothelial cells to undergo apoptosis (Hasan et al., 2000).

\section{Histiocytoma}

A histiocyte is an older name for a cell of the myeolid stem cell line; i.e. a macrophage or a dendritic cell. Macrophages function as sentinel cells in the immune system with the ability to act as a non-specific effector cells. Different lines of macrophages exist, and their names are dependant on location, for instance, the macrophages in the brain are called microglia, macrophages lining the liver endothelia are called Kuppfer cells and macrophages found in the lungs go by the name alveolar macrophages. Dendritic cells play a crucial part in the immune system, being the most important antigen presenting cells (APC). As with the macrophages, there are different subtypes of dendritic cells with varying denominations usually alongside slightly differentially expressed cell surface markers (Fulmer \& Mauldin 2007). 


\section{Descriptive features}

In dogs, especially those younger than three years old, cutaneous histiocytoma is a common neoplasm. It usually appears as a single lesion of flat or nodular character and regresses within 1-2 months. On microscopical evaluation, the tumour displays an infiltrative growth in the superficial and the deeper layer of the dermis (Fulmer \& Mauldin 2007). To determine the origin of canine cutaneous histiocytoma $(\mathrm{CCH})$, immunochemistry was performed on tumour tissue samples (Moore et al., 1996). The result was that the neoplastic cells in the histiocytoma were expressing cell surfaces markers such as CD1, CD11a, CD11c, E-cadherin and MHCII, some of them specific for Langerhans cells (LC), a dendritic cell seen in the epidermis. Additionally, some of these markers are associated with maturing LCs. When a LC differentiates in to a mature cell, it migrates to the paracortex in the regional lymph nodes. Despite this, the neoplastic LCs remained in the epidermis. It was therefore concluded that the $\mathrm{CCH}$ originates from Langerhans cells and have a tropism for the epidermis.

\section{Findings in the regression stage}

As previously mentioned, histiocytomas in dogs are renowned regressing tumours. The mechanism behind this process is thought to be regulated by the immune system. In 2006, Kaim et al. (2006) performed a study to elucidate the composition of cytokines and immune cells in histiocytomas at different stages of regression. Findings indicated an initial predominating abundance of $\mathrm{CD} 4^{+}$T-cells which later was inverted so that $\mathrm{CD} 8^{+}$cytotoxic $\mathrm{T}$ cells were the main cell type in the immunologic infiltrate. Furthermore, activated macrophages were found in the lesions. This correlated well with a significant expression of a number of cytokines that was also identified in the tumour; IL-2, TNF- $\alpha$, IFN- $\gamma$ and iNOS mRNA. The early infiltration of $\mathrm{CD}^{+}{ }^{+}$-lymphocytes was thought to be the inducing factor of regression, producing cytokines necessary for the following immune-response. Their release of IFN- $\gamma$ activates macrophages, stimulates the Th1-response and enhances cytotoxic activity in CTLs. IL-2, produced by the T-lymphocytes, stimulates T-cell proliferation as well as recruits lymphokine activated killer cells (LAKs). The up-regulated expression of iNOS mRNA probably serves to promote the formation of nitric oxide (NO), a reactive metabolite, active in the intracellular lysosomes in macrophages. Based on these findings, a conclusion was drawn, stating that the regression of histiocytoma is dependant on a CTL-response initiated by activated $\mathrm{CD}^{+} \mathrm{T}$-cells and supported by phagocytic myeloid cells. The authors speculated that the activation of the $\mathrm{CD}^{+}$T-lymphocytes could be induced by antigenpresentation performed by the neoplastic Langerhans cells, thus making it a self-limiting neoplasm (Kaim et al., 2006).

\section{Papilloma}

\section{Virus-induced papilloma}

Specific papillomaviruses exist for most species, generally causing benign tumours and on rare occasions malignant growths. The virus infects cells in the suprabasilar layer in the squamous epithelium. Dependant on the insertion of the viral genome, two types of papilloma can evolve. The cells can become hyperactive, highly mitotic and proliferative; leading to 
hyperplasia and hyperkeratosis. The cells can also degenerate, have a nuclear located production of virions and eventually die. Clinical lesions are usually shown as alopecic, flat to papular hyperplastic formations. A thickened stratus spinosum of the dermis is seen histologically, covered by a pathologically larger layer of parakeratotic or orthokeratotic keratin. In some papillomas, "koilocytes" are visible. This term describes swollen keratinocytes with a characteristic perinuclear halo and a peculiar nucleus (McGavin \& Zachary 2007).

\section{Mechanisms of regression}

Papillomas are known to spontaneously regress. In this phase the infected cells move away from the peribasal layer in the epidermis, escaping possible immunologic attack since the higher layers receive a lesser blood supply and thus a lesser number of circulating antigendetecting cells (McGavin \& Zachary 2007).

A study made on oral keratinocytes infected with human papilloma virus (HPV) presented evidence that the cells underwent terminal differentiation and consequently lost their ability to proliferate. The cells became anucleated, squamous and more keratinized and the ratio of differentiated cells versus the basal-horny cells steadily increased with time. The keratinized cells stopped expressing proliferative cell nuclear antigen (PCNA), but expressed high levels of involucrin and high molecular weight keratin, both important markers of differentiation of keratinocytes. Eight weeks post infection, the tissue was infiltrated by immunologic cells, dominating the histological compound. Multinucleated foreign body type giant cells were disposing of keratinous debris and dystrophic microcalcifications could be seen within the regressing papilloma (Yoo et al., 2002).

These findings suggest that the mechanisms behind regression of virus-induced papilloma are based on terminal differentiation of the keratinocytes, thus leading to a loss of ability to proliferate, followed by an immune-response from the host to discard the infected cells.

\section{DISCUSSION}

As shown above, there are still many question marks surrounding the events of natural regression in some tumours. For both hemangioma and mastocytoma, apoptosis seems to hold a key role in the involuting process, judging from the arrested proliferation and the dramatically increased numbers of apoptotic cells. Still, there are no obvious inducers of apoptosis. In hemangioma, theories suggest that the mast cell is the promoting factor of apoptosis (Boon et al., 1996; Hasan et al., 2000; Ritter et al., 2001). Could further investigation reveal a similar mechanism in the regression of mastocytoma? A possible explanation could be non-neoplastic mast cells forcing the monoclonal tumour cells to undergo self-generated cell death according to the same pattern as in the regressing hemangioma.

In canine cutaneous histiocytoma, an inflammatory response serve as a reliable theory as to why the tumour undergoes involution. Theories suggest that the initiation of the regression is a consequence of neoplastic LCs with antigen presenting ability, activating $\mathrm{CD}^{+}{ }^{+} \mathrm{T}$-cells 
which moreover promotes a CTL-mediated immune-response (Kaim et al. 2006). In the case of the MeLiM-pigs, tumour regression seems to be a consequence of the tumour cells being highly immunogenic and expressing specific tumour antigens which triggers an immuneresponse (Rambow et al., 2008). Immune reactions to tumour cells is documented in other types of neoplasms as well and research has been done on the cytokines produced, triggering both cellular, mainly cytotoxic T-lymphocytes and natural killer cells (NK-cells) and humoral immune responses (Xiang et al., 2001)

Terminal differentiation of the keratinocytes is responsible for the regression of papillomas. When the cell differentiates to the final stage, it loses its ability to undergo mitosis. Thus, the tumour progression is halted and eventually the tumour cells are exfoliated and the tumour is completely involuted and replaced with new non-neoplastic epidermal cells (Yoo et al., 2002).

The MeLiM-pigs pathogenesis and regression of cutaneous malignant melanoma has been studied more in depth by performing SSH to determine changes in the gene-expression throughout the period of regression (Rambow et al., 2008). The results presented a clear overview of what genes that were up- or down-regulated compared to the proliferating phase, which favours the chances of discovering what factors might cause the switch. This information could be of the utmost value to the development of therapies designed to treat malignant melanoma, the most aggressive of skin cancers.

All of the examples presented in the literature review are tumours of the skin. It would be interesting to further investigate why dermatological tumours are more likely to undergo spontaneous regression than other tumours, if there are features connected to the tissue itself that trigger the self-generated remission or if it is merely a coincidence.

Hemangioma, mastocytoma, histiocytoma and the spontaneously regressing melanomas in Lichenov mini-pigs all undergo both a proliferative and a regression phase at a very early stage in life, as opposed to the most common neoplasms that occur late in life. In MeLiMpigs, this can be explained by the species suffering from the effects of heavy inbreeding and subsequently, being extremely susceptible to the development of malignant melanoma (Vincent-Naulleau et al., 2004). In the other cases, no confirmed theory has been presented. Could the early tumour development be associated with the pathogenesis of all four tumours? Is there possibly a connection to placental origin of the tumour tissue that triggers the proliferation, and is the tumour then defeated by mechanisms in the individual's own immune-system?

As shown above, spontaneous tumour regression can be a case of destruction by the innate immune response, terminal differentiation of tumour cells or increased apoptosis of tumour cells. It is very difficult to sum up the phenomenon of the natural occurring involution of tumours since the underlying mechanisms seem to alter with each tumour type. It can be concluded that the pathogenesis of a tumour has a crucial impact upon regression. Moreover, the definite trigger of the switch to regression remains unknown in most cases. More research needs to be done in this field to further elucidate the possible explanations as to how and why tumours undergo remission without external treatment. 


\section{REFERENCES}

Boon, L.M., Enjolras, O. \& Mulliken, J.B. (1996). Congenital hemangioma: evidence of accelerated involution. The Journal of Pediatrics, 128(3), 329-335.

Bruckner, A.L. \& Frieden, I.J. (2003). Hemangiomas of infancy. Journal of the American Academy of Dermatology, 48(4), 477-493

Elston, D.M. (2004). Mechanisms of regression. Clinical Medicine \& Research, 2(2), 85-88.

Fulmer, A.K. \& Mauldin, G.E. (2007). Canine histiocytic neoplasia: An overview. The Canadian Veterinary Journal, 48(10), 1041-1050.

Hartmann, K., Hermes, B., Rappersberger, K., Sepp, N., Mekori, Y.A. \& Henz, B.M. (2003). Evidence for altered mast cell proliferation and apoptosis in cutaneous mastocytosis. The British Journal of Dermatology, 149(3), 554-559.

Hartmann, K. \& Henz, B. (2001). Mastocytosis: recent advances in defining the disease. British Journal of Dermatology, 144(4), 682-695.

Hasan, Q., Rüger, B.M., Tan, S.T., Gush, J. \& Davis, P.F. (2000). Clusterin/apoJ expression during the development of hemangioma. Human Pathology, 31(6), 691-697.

Hasan, Q., Tan, S.T., Gush, J. \& Davis, P.F. (2001). Altered mitochondrial cytochrome b gene expression during the regression of hemangioma. Plastic and Reconstructive Surgery, 108(6), 1471-1476; discussion 1477-1478.

Inoue, T. Yoneda, K., Kakurai, M., Fujita, S., Manabe, M. \& Demitsu, T. (2002). Alteration of mast cell proliferation/apoptosis and expression of stem cell factor in the regression of mastocytoma - report of a case and a serial immunohistochemical study. Journal of Cutaneous Pathology, 29(5), 305-312.

Kaim, U., Moritz, A., Failing, K. \& Baumgärtner, W. (2006). The regression of a canine Langerhans cell tumour is associated with increased expression of IL-2, TNF-alpha, IFN-gamma and iNOS mRNA. Immunology, 118(4), 472-482.

Longley, B.J., Tyrrell, L., Lu, S., Ma, Y., Langley, K., Ding, T., Duffy, T., Jacobs, P., Tang, L.H. \& Modlin, I. (1996). Somatic c-KIT activating mutation in urticaria pigmentosa and aggressive mastocytosis: establishment of clonality in a human mast cell neoplasm. Nature Genetics, 12(3), 312-314.

McGavin, M.D. \& Zachary, J.F. (2007). Pathologic basis of veterinary disease. 4th edition. Elsevier Mosby. 1177 
Moore, P.F., Schrenzel, M.D., Affolter, V.K., Olivry, T. \& Naydan, D. (1996). Canine cutaneous histiocytoma is an epidermotropic Langerhans cell histiocytosis that expresses CD1 and specific beta 2-integrin molecules. The American Journal of Pathology, 148(5), 1699-1708.

Rambow, F., Piton, G., Bouet, S., Leplat, J., Baulande, S., Marrau, A., Stam, M., Horak, V. \& Vincent-Naulleau, S. (2008). Gene expression signature for spontaneous cancer regression in melanoma pigs. Neoplasia (New York, N.Y.), 10(7), 714-726, $1 \mathrm{p}$ following 726 .

Razon, M.J., Kräling, B.M., Mulliken, J.B. \& Bischoff, J. (1998). Increased apoptosis coincides with onset of involution in infantile hemangioma. Microcirculation (New York, N.Y.: 1994), 5(2-3), 189-195.

Ritter, M.R., Dorrell, M.I., Edmonds, J., Friedlander, S.F. \& Friedlander, M. (2002). Insulinlike growth factor 2 and potential regulators of hemangioma growth and involution identified by large-scale expression analysis. Proceedings of the National Academy of Sciences of the United States of America, 99(11), 7455-7460.

Valent, P., Horny, H.P., Escribano, L., Longley, J., Li, C.Y., Schwartz, L.B., Marone, G., Nuñez, R., Akin, C., Sotlar, K., Sperr, W.R., Brunning, R.D., Parwaresch, R.M., Austen, K.F., Lennert, K., Metcalfe, D.D., Vardiman, J.V. \& Bennett, J.M. (2001). Diagnostic criteria and classification of mastocytosis: a consensus proposal. Leukemia Research, 25(7), 603-625.

Vincent-Naulleau, S., Le Chalony, C., Leplat, J., Bouet, S., Bailly, C., Spatz, A., Vielh, P., Avril, M., Tricaud, Y., Gruand, J., Horak, V., Frelat, G. \& Geffrotin, C. (2004). Clinical and histopathological characterization of cutaneous melanomas in the melanoblastoma-bearing Libechov minipig model. Pigment Cell Research / Sponsored by the European Society for Pigment Cell Research and the International Pigment Cell Society, 17(1), 24-35.

Xiang, J., Chen, Z., Huang, H. \& Moyana, T. (2001). Regression of engineered myeloma cells secreting interferon-gamma-inducing factor is mediated by both CD4(+)/CD8(+) T and natural killer cells. Leukemia Research, 25(10), 909-915.

Yoo, G.H., Piechocki, M., Lonardo, F., Menh, H., Kewson, D., Shibuya, T.Y., Kim, H., Stachler, R. \& Ensley, J.F. (2002). In vivo characteristics of HPV-immortalized and carcinogen transformed oral keratinocytes. The Laryngoscope, 112(9), 1672-1679. 